\title{
Note on Spelling and Pronunciation
}

In the period covered by this book at least five different languages were spoken as vernaculars in the territories that now make up Scotland and many of the written records of the age were produced in a sixth language, Latin. In the representation of personal names (and a handful of technical terms) I have tried to adopt a consistent policy.

GAELIC

Names which were current in Gaelic are represented in the standard Middle Irish form which represents the established written forms of the age. This rule has been adopted partly because it is the closest we can come to a true representation of the names as they would have sounded to the people who bore them, and partly because the vast majority of the source materials for Scottish Gaels in this period were written in Ireland and deal largely with Irish affairs. Since Irish historiography has long since abandoned the use of modern anglicised forms for early medieval names, such as Angus and Donald for Óengus and Domnall, and since we are dependent upon editions of chronicles and other medieval texts undertaken by students of Irish history it is only sensible to follow their practice in representing medieval names.

Early Gaelic orthography is not simple but what follows presents a basic guide.

At the beginning of words most consonants have the same value as in modern English with the caveat that ' $c$ ' is pronounced as ' $k$ '. In the middle or at the end of words, however, the following consonants tend to have modified values as indicated: 


$$
\begin{aligned}
& \mathrm{c}=\mathrm{g} \\
& \mathrm{p}=\mathrm{b} \\
& \mathrm{t}=\mathrm{d} \\
& \mathrm{b}=\mathrm{v} \\
& \mathrm{d}=\mathrm{d} \text { [where ' } \mathrm{d} \text { ' }=\text { the sound at the end of English 'with'] } \\
& \mathrm{g}=\mathrm{y} \text { [ as in 'youth'] } \\
& \mathrm{m}=\mathrm{v} \\
& \mathrm{f}=[\text { [ }[\text { that is, it becomes silent }]
\end{aligned}
$$

In some compound names the initial consonant of a name is preceded by a lower case consonant, for example, Cenél n Gabráin meaning 'kindred of Gabrán', in such cases the 'true' initial is replaced by the lower case prefix so, in this case we pronounce 'Kenél Navráin'. The digraph 'th' is voiced much as in modern English and 'ch' as in 'loch'. ' $\mathrm{S}$ ' is sounded as 'sh' before ' $i$ ' and 'e'.

Accents on vowels signify their length and also give some indication of where to lay stress in the word. If the letter 'e' appears at the end of a name, following a consonant it should be pronounced (unlike English 'stone' or 'lime').

Some common names:

Domnall $=$ Dovnal

Oengus $=$ Oinyus

Cinaed $=$ Kiney $ð$

Aed $=$ Eyð

Mael Sechnaill $=$ Malshechnal

There is also something called an 'epenthetic' vowel which appears between an 'l' or ' $r$ ' and an immediately following consonant. It is little more than a pause for breath and is perhaps best represented by an apostrophe: Alba = Al'ba, Colmán = Kol'maan.

\section{BR ITISH/CUMBR IC/WELSH}

The British Celtic language was widely spoken across Britain and in northwestern France during the early middle ages. This language is the ancestral language of modern Welsh, Cornish and Breton, although at this period most its dialects were not distinct enough to be classed as separate languages. Some historians of Scotland and northern England have, in recent decades, begun the habit of describing the British spoken in the north as 'Cumbric' but this is not really justified or necessary and one 
suspects that it is to some extent motivated by nationalistic concerns that the Welsh of today might claim northern British history and literature for themselves. Almost all the records of medieval British, barring a few names here and there, survive in manuscripts made in Wales in the central or later middle ages and thus it is sensible to keep in line with modern Welsh historiography, as we have kept in line with Irish historiography, to make cross-referencing easier. Unfortunately the Welsh tradition, in contrast to the Irish, has been to modernise name forms. Thus, in this book I have followed different conventions for the representation of British and Gaelic. In doing so, however, I have been maintaining the policy followed by the Scottish Historical Reviem, Scotland's premier periodical in this field.

Modern Welsh orthography is extremely consistent. Most letters are sounded as in English with the following exceptions:

$$
\begin{aligned}
& \mathrm{c}=\mathrm{k} \text { [without exception] } \\
& \mathrm{f}=\mathrm{v} \\
& \mathrm{ff}=\mathrm{f} \\
& \mathrm{ll}=\text { the sound in the middle of the word 'antler' } \\
& \mathrm{dd}=\mathrm{d} \\
& \mathrm{u}=\text { ' } \mathrm{i} \text { ' as in 'linen' } \\
& \mathrm{w}=\text { the vowel sound in 'cook' unless followed by a vowel in which case } \\
& \quad \text { it has the English value } \\
& \mathrm{y}=\mathrm{a} \text { [the neutral vowel, or 'schwa', found at the end of 'snooker'] } \\
& \quad \text { unless there are two 'y's in a word in which case the second is the } \\
& \quad \text { vowel in 'with' [thus Aberystmyth = 'Aberostwith'] } \\
& \mathrm{ch}=\text { 'ch' in loch } \\
& \mathrm{rh}=\text { 'hr' }
\end{aligned}
$$

Some common names:

Dyfnwal $=$ Dovnooal $[$ the Gaelic name Domnall is probably a borrowing of this name]

Owain $=\mathrm{O}+$ 'wine'

Rhydderch $=$ Hrəðerch

\section{PICTISH BRITISH}

English and Irish writers of the early middle ages seem to have believed that the Picts had their own language which was distinct from British. Unfortunately, no extended texts written in the language of the Picts 
survive and the place-names, personal names and a handful of loanwords which do survive are indistinguishable from British. In the I950s Kenneth Jackson suggested that there had been two Pictish languages, one a dialect of British and the other of non-Celtic origin. This view is not as popular as it once was, although it is not entirely without supporters. In this book I have chosen to describe the British spoken in Pictavia as 'Pictish British', on the analogy of 'Scottish Gaelic', thus stressing both its common heritage with British and its distinctive character. The possible relationship between Pictish British and other British dialects is discussed at length in Chapter 8, here it is only necessary to discuss briefly its orthography. Our understanding of Pictish British orthography is based almost exclusively on the Pictish version of the Pictish kinglist. The one liberty I have taken in this book is to represent the common letter cluster 'uu' as 'w'. Below are some Pictish names in the three Celtic orthographies:

$\begin{array}{lll}\text { Pictish British } & \text { British (Welsh) } & \text { Gaelic } \\ \text { Onuist } & \text { Ungust } & \text { Oengus } \\ \text { Wrguist } & \text { Gwrwst } & \text { Fergus } \\ \text { Wen } & \text { Owain } & \text { Eogan(án) } \\ \text { Bridei } & \text { Brydw } & \text { Brude } \\ \text { Naiton } & \text { Neithon } & \text { Nechtan }\end{array}$

\section{OLD ENGLISH}

Most of the sound values in Old English, the language of the AngloSaxons, were similar to those in modern English. It is generally the case that historians of the Anglo-Saxon period standardise name forms to the Late West Saxon spelling system and that pattern has been followed here. It should be noted, however, that when names end in 'e', like Oswine, the final 'e' should be voiced and does not effect the preceding 'i' - this is 'Os' + 'win' + 'e' not 'Os' + modern English 'wine'. The major differences lies in the existence of certain characters not retained in modern English:

$\delta=$ 'eth' and represents the consonant at the end of 'with'

$p=$ 'thorn' and represents the sound at the beginning of that word (yes, it is different from $ठ$ )

$æ=$ 'ash' and represents the vowel in that word (although it eventually became an 'eh' sound). 
The pronunciation of the letter 'c' varies according to its 'environment'. Before or after 'i' and before ' $e$ ' this is sounded like 'ch' in English 'church'. Thus, the town now called Sandwich was originally spelt Sandwic. The cluster 'cg' is sounded like modern English 'dg' - thus Ecg- = 'edge'.

Some common names:

Ceolwulf $=$ 'Cheolwolf'

Æðelstan = Athelstan

Ecgfrið = Edgefrith

\section{OLD NORSE}

The Scandinavians learned to write from the English and thus for the most part used the same spelling system with the exception that they used ' $k$ ' rather than 'c' and this character consistently represented a hard ' $k$ ' sound. 
